\title{
Holocene paleoenvironmental change inferred from two sediment cores collected in the Tibetan lake Taro Co
}

\author{
Andreas Laug (i) - Torsten Haberzettl • Andre Pannes • Anja Schwarz • \\ Falko Turner · Junbo Wang $\cdot$ Stefan Engels $\cdot$ Sonja Rigterink $\cdot$ \\ Nicole Börner $\cdot$ Marieke Ahlborn · Jianting Ju • Antje Schwalb
}

Received: 10 November 2020/ Accepted: 8 May 2021/Published online: 18 July 2021

(C) The Author(s) 2021

\begin{abstract}
The Tibetan Plateau, also known as the "Water Tower of Asia" because of its function as a water storage and supply region, responds dramatically to modern climate changes. Paleoecological shifts inferred from lake sediment archives provide essential insights into past climate changes, and the processes that drove those shifts. This is especially true for studies of lakes in endorheic basins on the Tibetan Plateau, where lake level is regulated predominantly by Monsoon intensity. Such water bodies provide excellent opportunities to reconstruct past changes in humidity. Most paleolimnological investigations of lakes on the Tibetan Plateau, however, have involved the study of a single sediment core, making it
\end{abstract}

Falko Turner: Deceased 10.01.2017.

Supplementary Information The online version contains supplementary material available at https://doi.org/10.1007/ s10933-021-00198-6.

A. Laug $(\bowtie) \cdot$ A. Pannes · A. Schwarz ·

F. Turner - S. Rigterink · N. Börner .

M. Ahlborn - A. Schwalb

Institute of Geosystems and Bioindication, Technische

Universität Braunschweig, Langer Kamp 19c,

38106 Brunswick, Germany

e-mail: a.laug@tu-braunschweig.de

T. Haberzettl

Institute for Geography and Geology, Physical

Geography, University of Greifswald, Friedrich-Ludwig-

Jahn-Str. 16, 17489 Greifswald, Germany difficult to discern between changes caused by local events and those caused by lake-wide or regional processes. Here we present results from a paleolimnological study of Lake Taro Co, a currently closedbasin lake in Central Tibet. We compared a sediment record from the central part of the lake to a record from the near-shore area, and present results of sedimentological and bioindicator (chironomid, diatom, pollen) analyses from both records. Results show three periods of lake-wide ecosystem change ( $>$ ca. 5250, 5250-2250 and $<$ since about 2250 cal year BP), which reflect a continuous drying trend throughout the Middle and Late Holocene. In addition to this lakewide trend, we identified two local events in the sediment core from the southeastern, nearshore site. These include (1) a hiatus between 12,400 and 5400 cal year BP and (2) an 1800-year period of distinct paleoenvironmental conditions (5400-3600 cal year BP). We hypothesize that both

J. Wang · J. Ju

Key Laboratory of Tibetan Environment Changes and Land Surface Processes (TEL)/Nam Co Observation Research Station (NAMORS), Institute of Tibetan Plateau Research, Chinese Academy of Sciences, Beijing 100101, People's Republic of China

S. Engels

Department of Geography, Birkbeck University of London, 32 Tavistock Sq., London WC1H 9EZ, UK 
events were caused by relocation of a river in the southeast sector of the lake's catchment. We propose that the first relocation caused an erosion event that removed sediment, thereby producing the hiatus. During the following 1800 years, the core site may have been located on the river delta, before another river relocation at 3600 cal year BP established the modern prodelta situation. Our study demonstrates the value of using multiple sediment cores from a lake, to better identify processes that control widespread versus local events.

Keywords Monsoon - Chironomidae - Diatoms · Geochemistry $\cdot$ XRF $\cdot$ Paleolimnology

\section{Introduction}

The majority of Earth's ecosystems are experiencing major changes as a result of anthropogenic climate change (Malhi et al. 2020). One of the most strongly affected regions is the Tibetan Plateau (TP). It is not only affected by warming that is roughly twice the global average (Anslan et al. 2020), but also by changes in the Indian and East Asian Monsoon systems (Haberzettl et al. 2019). Both are intensifying because of climate warming, thereby enhancing water transport to the TP (Zhang et al. 2017). Therefore, dramatic environmental changes are occurring all over Tibet, including melting of glaciers (Yao et al. 2007) and rising lake levels (Jiang et al. 2017). These changes impact Tibetan ecosystems and the region's function as the "Water Tower of Asia," i.e. its ability to store and supply water, which provides a crucial service for the surrounding, densely populated regions (Immerzeel et al. 2010). Some climate-induced changes, such as the ongoing melting of glaciers, can be reliably predicted using models based on physical variables (Zhao et al. 2014). Other changes, however, such as ecosystem responses, are harder to predict. Our understanding of such possible responses can be improved by studying past ecosystem dynamics

M. Ahlborn

Institute of Geography, Friedrich-Schiller-University

Jena, Löbdergraben 32, 07743 Jena, Germany
(Schwarz et al. 2017; Laug et al. 2020a; Ma et al. 2020).

Closed-basin lakes are particularly well-suited for studies of past humidity changes. As a result of differing water supply and evaporation through time, water levels in these systems rose and fell, and salinities decreased or increased (Haberzettl et al. 2015; Gyawali et al. 2019). Reliable climate and ecosystem reconstructions from Tibetan lake sediments have been accomplished using a range of paleoecological methods, including sedimentological and geochemical information (Kasper et al. 2012), fossil material from fauna such as chironomids (Brooks et al. 2007) and ostracods (Börner et al. 2017; Alivernini et al. 2018), diatoms (Schwarz et al. 2017; Yu et al. 2019), as well as terrestrial remains transported into the lake, such as pollen (Ma et al. 2014, 2020). Each of these bioindicators has strengths and weaknesses, but it is their combination, in a multiproxy approach, that enables reliable paleoclimate and paleoenvironmental inferences (Birks and Birks 2006).

Most paleolimnological investigations use only a single sediment core, often collected from the central part of the lake (Ma et al. 2014; Guo et al. 2016). Some environmental shifts are recorded throughout the entire lake, whereas others may affect only local areas or certain habitats (Turner et al. 2016; Kou et al. 2020). Therefore, comparison of sediment cores from different locations, in addition to analysis of multiple sediment variables, can improve the outcome of a paleoecological study (Digerfeldt 1986).

\section{Site description}

Taro Co is a large, oligotrophic fresh to brackish water lake (0.6 $\mathrm{g} \mathrm{L}^{-1}$ TDS, Alivernini et al. 2018) with a maximum depth of $132 \mathrm{~m}$ (Guo et al. 2016). It is located at $4567 \mathrm{~m}$ a.s.l. in the western part of the Central TP $\left(31^{\circ} 03^{\prime}-31^{\circ} 13^{\prime} \mathrm{N}, 83^{\circ} 55^{\prime}-84^{\circ} 20^{\prime} \mathrm{E}\right.$, Fig. 1). Although it was hydrologically connected to a larger lake system in the past, today it is a closed-basin lake that extends over an area of $488 \mathrm{~km}^{2}$ (Alivernini et al. 2018). The lake water has a mean alkalinity of $6.9 \mathrm{mmol} \mathrm{CaCO}_{3} \mathrm{~L}^{-1}$, a $\mathrm{pH}$ of 9.4 , and possesses oxygen throughout the entire water column year-round (Alivernini et al. 2018; Turner et al. 2016). The lake is located in a high-alpine, continental climate (mean annual temperature $0-2{ }^{\circ} \mathrm{C}$ ) and is fed mainly by 


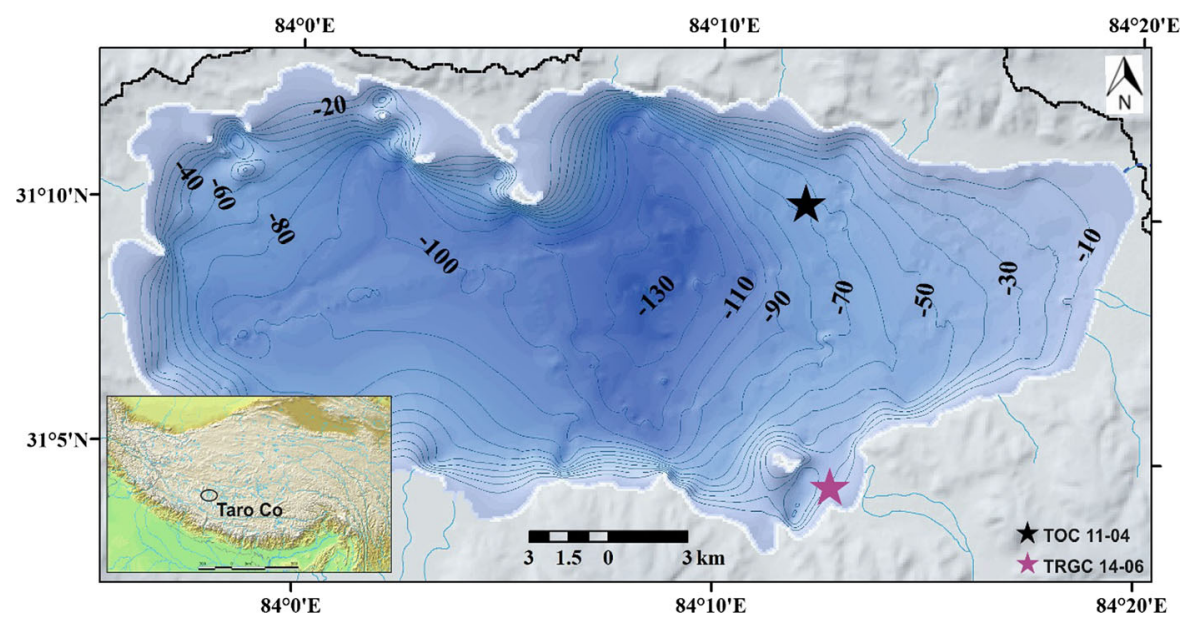

Fig. 1 Location of Lake Taro Co on the Tibetan Plateau. Locations of sediment cores TOC 11-04 (black asterisk) and TRGC 14-06 (purple asterisk) are indicated. Bathymetric map

precipitation from the Indian Summer Monsoon and glacial meltwater, which originates mainly from the high Gangdise Mountains, which rise to $7095 \mathrm{~m}$ a.s.1. (Zheng et al. 1989). The 7000- $\mathrm{km}^{2}$ lake catchment is covered by alpine steppe and alpine meadow, and the bedrock consists of mudstone, siltstone, conglomerates, marine clastic rocks, siliceous mudstone and marlstone (Ma et al. 2014). Over the last few decades, the lake increased slightly in size (Wu et al. 2017), and terraces in the catchment provide evidence of past lake highstands, up to $53 \mathrm{~m}$ higher than today (Alivernini et al. 2018).

The aims of this study were to use chironomid, diatom and sedimentological data in two sediment cores from Lake Taro Co, Central Tibet to: (1) reconstruct lake-wide ecosystem shifts during the Holocene in the basin, (2) distinguish between local and lake-wide changes in the ecosystem, and (3) identify possible causes of local events.

\section{Materials and methods}

Field sampling

Two sediment cores were collected from different sites in the lake, using a gravity corer. A 121-cm-long core was collected from the central part of the lake during a 2011 field campaign (TOC 11-04, 68 m water depth). The second core is $135 \mathrm{~cm}$ long, and was modified from Guo et al. (2016). Overview map source: http:// www2.demis.nl/worldmap/mapper.asp (accessed 17.03.2021)

recovered from a sub-aquatic prodelta near the southeastern shore (TRGC 14-06, $29.4 \mathrm{~m}$ water depth), during field work in 2014. Core TOC 11-04 was transported to the laboratory of the Physical Geography Department of the Friedrich-Schiller-University Jena, Germany, where it was stored under dark and cool $\left(+4{ }^{\circ} \mathrm{C}\right)$ conditions prior to processing. The core was split lengthwise, photographed and the sediments were described according to standard protocols. Core TRGC 14-06 was treated similarly at the Institute of Tibetan Plateau Research, Chinese Academy of Sciences, Beijing. Sediment cores were analyzed for sedimentological and geochemical characteristics (grain size, organic and inorganic carbon, elemental concentrations) and paleoecological bioindicators (chironomids, diatoms, pollen).

\section{Chronology}

Six bulk sediment samples from TOC 11-04, and nine samples from TRGC 14-06, the three lowermost being bulk sediment and all others plant material (Electronic Supplementary Material [ESM] Table S1), were radiocarbon-dated by accelerator mass spectrometry (AMS) at Beta Analytic, Inc. (Miami, USA). One surface sample from each core was dated to assess the present-day reservoir effect, which was assumed to have remained constant over time. The surface age was subtracted from each of the radiocarbon ages before calibration (ESM Table S2). After reservoir 
correction and calibration using the IntCal20 data set (Reimer et al. 2020), age-depth models were developed using the $\mathrm{R}$ software package Bacon (Blaauw and Christen 2011). The resulting chronology for TOC 11-4 was tested and confirmed using paleomagnetic secular variation (PSV) stratigraphy (Haberzettl et al. 2015). Paleomagnetic analyses of TRGC 14-06 were unsuccessful, probably because particles in this core are too coarse.

\section{Geochemical analyses}

Semi-quantitative scans of inorganic elemental composition were carried out at 2-mm resolution on TOC 11-04 and at 1-mm resolution on TRGC 14-06, using ITRAX XRF-core scanners. Double-L-channels (Nakagawa 2007) were taken from TOC 11-4 and subsampled at contiguous $1-\mathrm{cm}$ intervals for analysis of grainsize, total nitrogen (TN), total inorganic (TIC) and total organic carbon (TOC). For grain-size analysis, samples were pretreated with $\mathrm{H}_{2} \mathrm{O}_{2}(10 \%)$ and $\mathrm{HCl}(10 \%)$ to degrade organic matter and dissolve carbonates, respectively. Dispersion of grains was achieved using sodium pyrophosphate and samples were shaken for $2 \mathrm{~h}$. Grain-size distribution was measured in seven cycles of $60 \mathrm{~s}$ each on an LS 13,320 Beckmann Coulter Counter, and the first reproducible signal was used for interpretation, applying the Fraunhofer optical model and a modified version of Gradistat 4.2 (Blott and Pye 2001) for sand, silt and clay content determination. Samples for TIC and TOC analyses were freeze-dried and ground $(<40 \mu \mathrm{m})$. Total carbon (TC) and TN were measured using an elemental analyzer (Vario El Cube). Subsequently, carbonates were dissolved with $\mathrm{HCl} 30 \%$ p.a. prior to the measurements of TOC with the same device. TIC was calculated as the difference between $\mathrm{TC}$ and TOC and molar $\mathrm{C} / \mathrm{N}$ ratios were calculated using TOC and TN.

\section{Chironomids}

For chironomid analysis, 44 samples from each core were prepared following standard procedures (Brooks et al. 2007) and mounted in Euparal $\subset$ mounting medium. If sufficient material was available, the process was repeated until a minimum of 50 head capsules (HC), the recommended sufficient count sum for numerical analysis (Quinlan et al. 2001), were enumerated. Low head capsule concentrations in several samples made it impossible to count the recommended minimum number. Therefore, several samples from TOC 11-04 were combined prior to numerical analysis (ESM Table S3). Despite combining samples, one merged sample $(118-121.5 \mathrm{~cm})$ contained only $47.5 \mathrm{HC}$. Given the low biodiversity, we nevertheless decided to include this sample in subsequent analyses, although we acknowledge that numerical results for this sample are less reliable. For TRGC 14-06, one sample $(130.5 \mathrm{~cm})$ was excluded because the count sum was too low.

Identification of subfossil larval remains followed Brooks et al. (2007) and Laug et al. (2019). The most common morphotype, Micropsectra radialis-type, was split into three subtypes based on morphological differences. The subtype resembling the description by Oliver Heiri and used in Brooks et al. (2007), characterized by a median tooth with two notches, a white spot below the median tooth and a small spur on the antennal pedestal, is referred to as $M$. rad. type HEIRI. The main identification characteristics of M. rad. type $\mathrm{T} 1$ are a median tooth without notches, an indefinite light spot below the median tooth and a relatively large spur with sclerotized edges on the antennal pedestal. $M$. rad. type $\mathrm{T} 2$ is characterized by a median tooth with two notches, a distinct white spot below the median tooth and the absence of a spur on the antennal pedestal. Furthermore, this subtype features relatively short ventromental plates. Pictures of all three $M$. radialis subtypes, an identification tree, and detailed descriptions of the three subtypes in comparison to the genus Paratanytarsus, as well as pictures of the Tibetan chironomid Acricotopus indet. morphotype incurvatus, are provided in ESM Figs. S1-4 and Tables S4, S5. For one sample (83 cm), distinguishing the $M$. radialis subtypes was extrapolated after counting 20.5 out of 55.5 Micropsectra and Paratanytarsus head capsules, because the original microscope slide was broken. Chironomid concentrations were calculated using count numbers from freeze-dried and wet samples in relation to the calculated dry weight based on water content measurements during the freeze-drying process.

\section{Diatoms}

For diatom analysis, 22 and 35 samples from TOC 11-04 and TRGC 14-06, respectively, were processed 
following standard procedures, including addition of divinylbenzene microspheres for determination of diatom concentrations (Battarbee and Kneen 1982). The resulting suspension was diluted, dried and mounted in Naphrax ${ }^{\circledR}$. If possible, 400 valves per sample were counted. Diatom species were identified mainly using Houk et al. (2010, 2014) and LangeBertalot (2017), and updated taxonomically following Mohan et al. (2018). For some small planktonic diatoms, most notably Lindavia biswashanti Mohan and Stine and Pantocsekiella ocellata Pantocsek, distinguishing under the light microscope was not always possible. These species were thus combined in the taxon "small Cyclotella sensu latu (s.l.) group."

Pollen

For pollen analysis, 31 samples from TOC 11-04 were analyzed following standard procedures. Identification followed Beug (2004). For graphical representation and interpretation within the scope of this study, only the ratio of Artemisia to Cyperaceae pollen was used.

\section{Data repository}

Datasets for all variables (geochemical analyses, chironomids, diatoms and pollen) analyzed in this
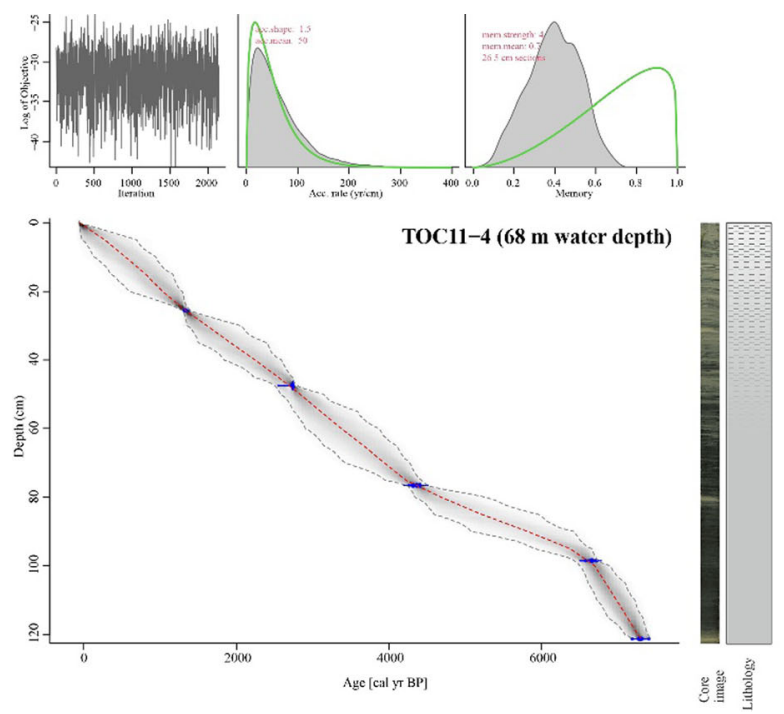

study are published in the online database Pangaea (https://doi.pangaea.de/10.1594/PANGAEA.927803).

Numerical analysis

For numerical analyses, taxa that occurred in abundances of $\leq 2 \%$ were considered rare. Zonation of the downcore diagrams was established independently for each core. In the first instance, percentages of non-rare chironomids were used in a cluster analysis (Everitt 2011), and the number of statistically significant zones was determined using a broken-stick model (Bennett 1996). Broken-stick analysis suggested no statistically significant boundaries (ESM Figs. S5, S6), but to support interpretation, zone boundaries were established visually using the chironomid record, if they were supported by changes in other variables. Ages for the zone boundaries were rounded to the nearest century. All statistical analyses were performed with $\mathrm{R}$, using the 'vegan' package (Oksanen et al. 2016).

\section{Results}

\section{Chronologies}

TOC 11-04 spans 7300 years of continuous sedimentation (Fig. 2). The age-depth relationship over the entire sediment core is almost linear, with slightly
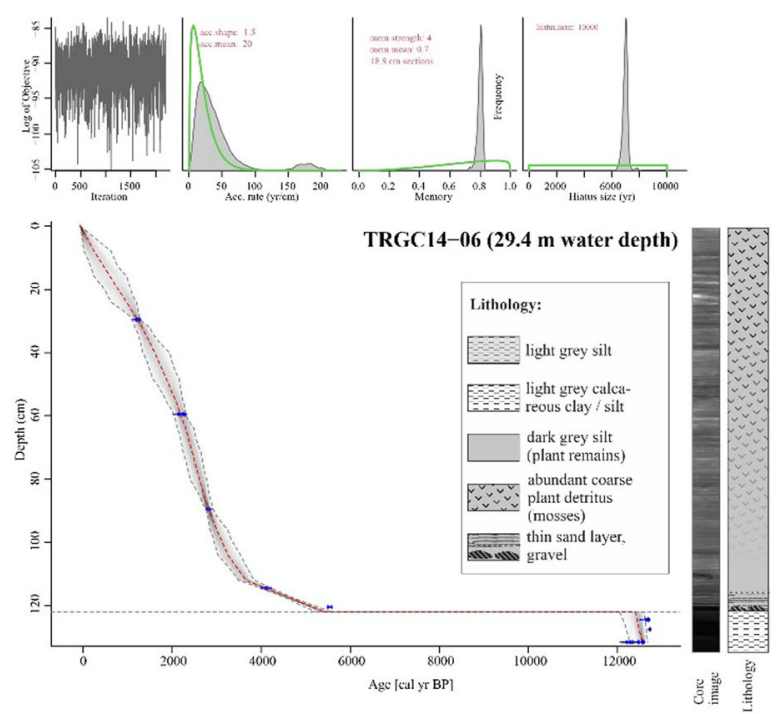

Fig. 2 Age-depth models of the sediment cores TOC 11-04 (left) and TRGC 14-06 (right), including core images and lithologies plotted to the right of each panel 
higher sedimentation rates observed before $5000 \mathrm{cal}$ year BP. A relatively small reservoir effect of $120 \pm 30$ years was observed and applied to the record (Fig. 2).

The sedimentation rate for core TRGC 14-06 was slightly higher than for core TOC 11-04 and the observed reservoir effect ( $80 \pm 30$ years) was slightly smaller than that of TOC 11-04. The upper $120 \mathrm{~cm}$ of TRGC 14-06 cover the entire time period from 5400 cal year BP to present. Samples below $122 \mathrm{~cm}$ were older than 12,400 cal year $\mathrm{BP}$, suggesting a hiatus of about 7000 years below this core depth (Fig. 2).

Central lake core (TOC 11-04)

Relatively homogenous, dark grey silt with faint laminations characterizes the lower part of the central lake core (121.4-50 cm; Fig. 2), whereas the upper $50 \mathrm{~cm}(<3000 \mathrm{cal}$ year BP $)$ are characterized by more frequent occurrences of layers of light grey silt
(Fig. 2). The chironomid samples from the central lake core contained on average 52.8 head capsules (HC) per sample (mean $=18.5 \mathrm{HC} \mathrm{g}^{-1}$ dry). Twentyone samples with low count sums were merged into eight samples to achieve count sums suitable for data analysis, leaving a final dataset of 31 samples (ESM Table S3). We identified a total of 43 taxa, of which 17 were considered rare. Samples analyzed for diatoms contained on average $20.7 \times 10^{7}$ valves per gram dry sediment. We identified a total of 130 taxa in the core from the central part of the lake. Based on the chironomid record, the central core (C) was divided into three zones (Figs. 3, 4, ESM Fig. S7).

\section{Zone C1: 7300-5100 cal year BP}

Zone $\mathrm{C} 1$ is dominated by Micropsectra radialis-type (55-80\%), which is the most common chironomid taxon throughout the core. All three M. radialis subtypes show similar abundances in this zone. Zone $\mathrm{C} 1$ shows low percentages of Paratanytarsus

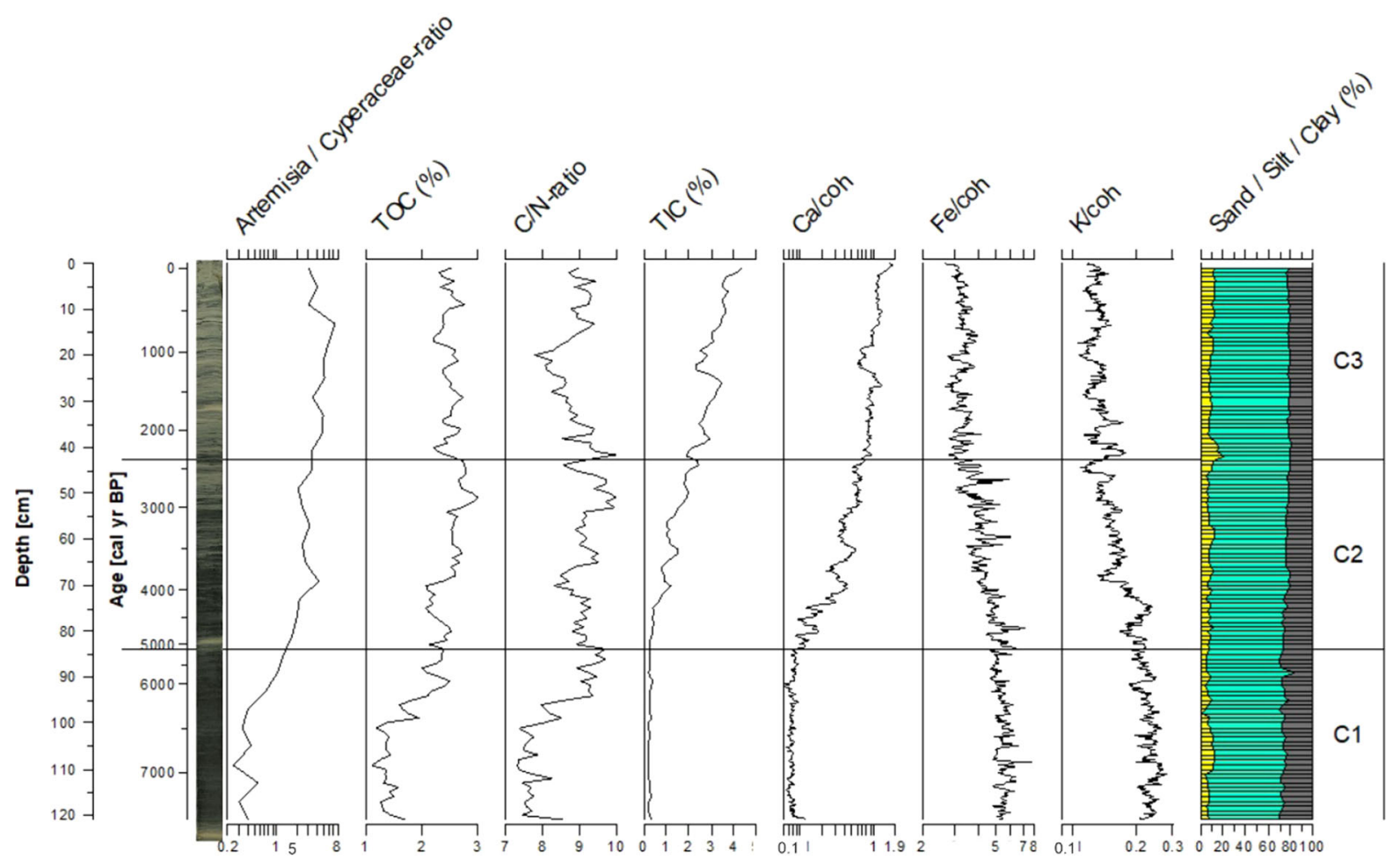

Fig. 3 Radiographic core image from the central core (TOC 11 04), Artemisia/Cyperaceae ratio, geochemical (TOC, C/N ratio, TIC, Ca, Fe, K) and grain size (yellow = sand, turquoise $=$ silt, grey $=$ clay). Note that Artemisia/Cyperaceae ratio and XRF data are plotted on a logarithmic scale. Data are plotted on a sediment depth scale (cm) with an age scale (cal year BP) for reference. Zonation (C1-C3) follows the chironomid assemblages. (Color figure online) 


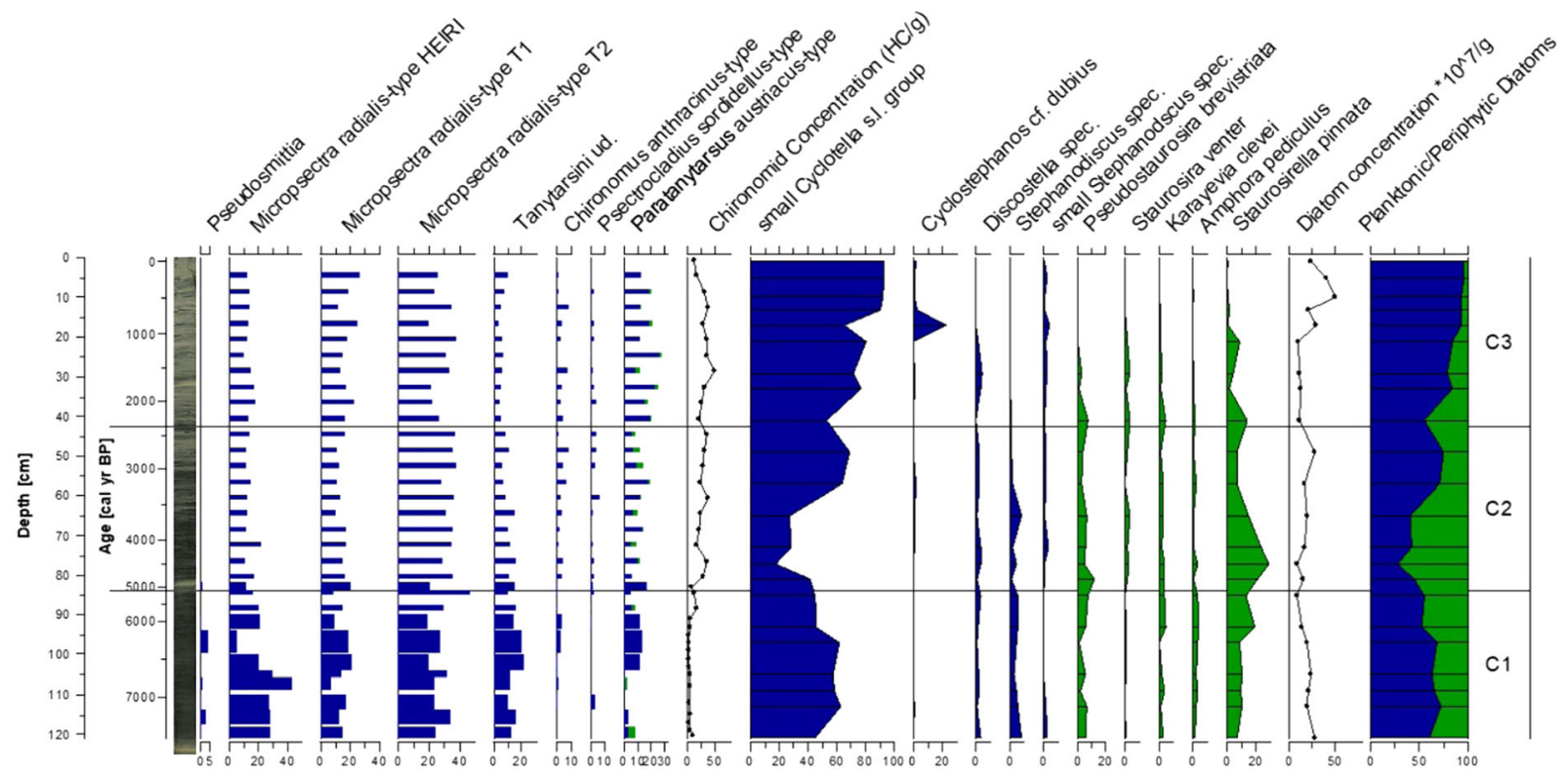

Fig. 4 Radiographic core image from the central-lake core (TOC 1104 ), selected chironomid and diatom taxa $(>4 \%)$ as percentages of their sums (blue bars $=$ chironomids, blue silhouettes = planktonic diatoms, green silhouettes $=$ periphytic diatoms), chironomid and diatom concentrations (per

(5-10\%) and Pseudosmittia ( $\leq 5 \%)$. Head capsule concentrations are the lowest of the entire core (on average $5.3 \mathrm{HC} \mathrm{g}^{-1}$ dry). Diatom assemblages of Zone $\mathrm{C} 1$ are dominated by valves of the planktonic "small Cyclotella s. 1. group" (50-60\%), accompanied by the periphytic Staurosirella pinnata (Ehrenberg) D.M. Williams and Round (10-20\%). The most abundant grain size in Zone $\mathrm{C} 1$ is silt $(60-70 \%)$, followed by clay $(25-30 \%)$ and sand $(5-10 \%)$. The Artemisia/Cyperaceae ratio, total organic carbon (TOC) and $\mathrm{C} / \mathrm{N}$ ratio are low for the first part of the zone and increase rapidly above $95 \mathrm{~cm}(6300 \mathrm{cal}$ year BP). Total inorganic carbon (TIC) and calcium (Ca) values are low, and those of iron $(\mathrm{Fe})$ and potassium (K) are high throughout Zone $\mathrm{C} 1$.

\section{Zone C2: 5100-2400 cal year BP}

Although still dominant in Zone C2, Micropsectra radialis-type occurs in lower abundances (50-60\%) than in Zone C1. This decrease is mostly the result of decreases of the subtypes $M$. radialis type HEIRI and $M$. radialis type $\mathrm{T} 1$. These two subtypes both show abundances up to $20 \%$, whereas $M$. radialis type $\mathrm{T} 2$ increases to $\sim 30 \%$ at the transition to Zone $\mathrm{C} 2$. gram dry sediment; black line with circle symbols) and the planktonic/periphytic diatom ratio (right). Data are plotted on a sediment depth scale $(\mathrm{cm})$ with an age scale (cal year BP) for reference. Zonation (C1-C3) follows the chironomid assemblages. (Color figure online)

Paratanytarsus increases slightly to $10-20 \%$, whereas Pseudosmittia disappears from the chironomid fauna. Chironomus anthracinus-type and Psectrocladius sordidellus-type are present at $\sim 5 \%$ throughout the zone. Head capsule concentrations increase abruptly at the onset of Zone $\mathrm{C} 2$, and stay relatively constant, at on average $26.5 \mathrm{HC} \mathrm{g}^{-1}$ dry. Zone $\mathrm{C} 2$ is the only section of the central lake core that shows periphytic diatoms in high abundances. Staurosirella pinnata, Staurosira construens Ehrenberg and Pseudostaurosira brevistriata (Grunow) D.M. Williams and Round, all present in Zone $\mathrm{C} 1$, reach maxima in Zone C2. In contrast, the planktonic "small Cyclotella s. 1. group" shows the lowest abundances of the record (20-40\%). Whereas the silt content is relatively stable, the clay content decreases in favor of sand during Zone C2. The Artemisia/Cyperaceae-ratio continues to rise and TOC and $\mathrm{C} / \mathrm{N}$ ratio stay high throughout Zone $\mathrm{C} 2$. Shortly after the onset of Zone C2, above $80 \mathrm{~cm}$ (4700 cal year BP), TIC and Ca values rise distinctly, and continue less markedly to the top of the record. Fe and $\mathrm{K}$ continuously decrease from the bottom to the top of the record, but most markedly in Zone C2. 
Zone C3: 2400 cal year BP to present

Micropsectra radialis-type is the most abundant chironomid morphotype in Zone C3, but shows lower abundances (35-45\%) compared to Zone C2. This decrease is the result of a decline in $M$. radialis type $\mathrm{T} 2$ to $20-30 \%$. While the abundances of Chironomus anthracinus-type and Psectrocladius sordidellus-type remain constant around 5\%, Paratanytarsus increases in abundance, up to $30 \%$. Head capsule concentrations stay at intermediate values (on average $29.7 \mathrm{HC} \mathrm{g}^{-1}$ dry). In Zone C3, all three periphytic diatom species decrease, whereas the planktonic "small Cyclotella s. 1. group" increases and reaches $93 \%$ in the most recent sample. The Artemisia/Cyperaceae ratio continues to rise throughout Zone $\mathrm{C} 3$, showing a slight reduction only in the three most recent samples. Whereas TOC remains high throughout the zone, the $\mathrm{C} / \mathrm{N}$ ratio decreases until $20 \mathrm{~cm}$ (1000 cal year BP) and increases thereafter. TIC and $\mathrm{Ca}$ values continue their rise, whereas $\mathrm{Fe}$ and $\mathrm{K}$ values display a falling trend throughout Zone $\mathrm{C} 2$.
Southeastern nearshore core (TRGC 14-06)

The southeastern nearshore core is characterized mostly by dark grey silt, with layers of coarse plant detritus, which are more abundant towards the top of the core (Fig. 2). Chironomid samples contained on average 110.8 head capsules per sample (mean $=54.3$ $\mathrm{HC} \mathrm{g}^{-1}$ dry). We identified a total of 40 chironomid taxa, of which 23 were considered to be rare. Samples analyzed for diatoms contained on average $13.0 \times 10^{7}$ valves per gram dry sediment. We identified a total of 87 mostly periphytic taxa. Based on the chironomid assemblages, the southeastern core (SE) was divided into four zones (Figs. 5, 6 and ESM Fig. S8).

\section{Zone SE1: 12,600-12,400 cal year BP}

Although the chironomid assemblages throughout the entire southeastern nearshore core are dominated by Micropsectra radialis-type, the lowermost zone (SE1) shows the lowest abundances of this taxon $(\sim 60 \%)$. The $M$. radialis-type specimens mainly belong to

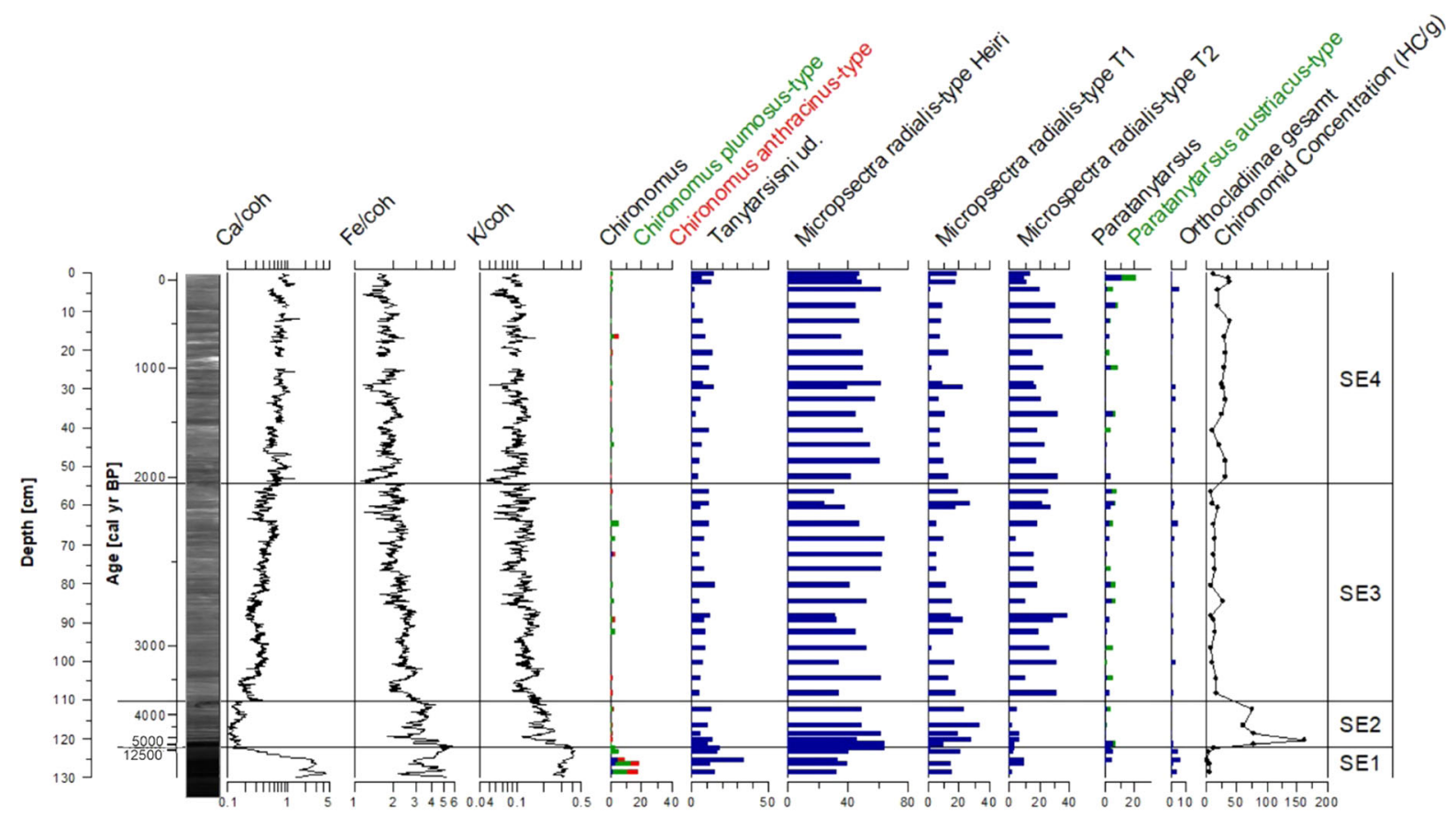

Fig. 5 Radiographic core image from the southeastern core (TRGC 14 06), geochemical results $(\mathrm{Ca}, \mathrm{Fe}, \mathrm{K})$ and selected chironomid taxa, shown as percentages of the chironomid sum (blue bars), with Chironomus and Paratanytarsus identified to morphotype level in green and red bars), chironomid concentrations (per gram dry sediment; black line with circle symbols). XRF data are plotted on a logarithmic scale. Data are plotted on a sediment depth scale (cm) with an age scale (cal year BP) for reference. Zonation (SE1-SE4) follows the chironomid assemblages. (Color figure online) 


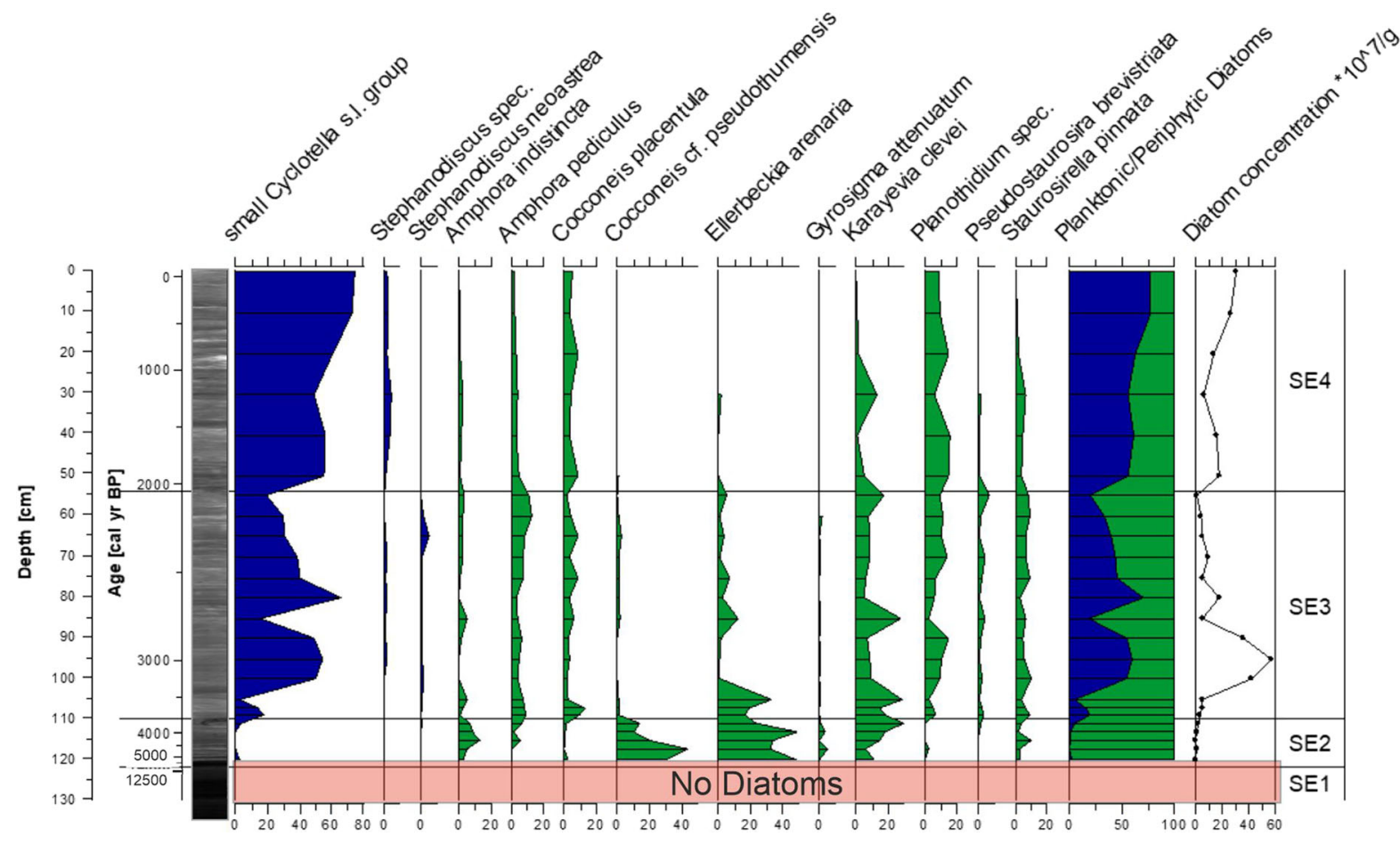

Fig. 6 Radiographic core image from the southeastern core (TRGC 1406 ), selected diatom taxa ( $>4 \%$ ), as percentages of their sums (blue silhouettes = planktonic diatoms, green silhouettes = periphytic diatoms), diatom concentrations (per gram dry sediment; black curves with circle symbols) and the

subtypes $M$. radialis type HEIRI $(\sim 40 \%)$ and $M$. radialis type $\mathrm{T} 1$ ( $\sim 20 \%)$. The subtype $M$. radialis type $\mathrm{T} 2$ accounts for $<5 \%$ of the chironomid sum in this zone. Zone SE1 is the only zone of the southeastern core that shows considerable abundances of the subfamily Orthocladiinae (in total $\sim 5 \%$ ), Chironomus anthracinus-type and C.plumosus-type ( $\sim 20 \%)$. Paratanytarsus shows abundances up to $5 \%$. Head capsule concentrations are the lowest of the entire core (on average $6.1 \mathrm{HC} \mathrm{g}^{-1}$ dry). In Zone SE1, diatom valves were dissolved. The sediment of Zone SE1 is characterized by light grey calcareous clay with minor amounts of silt. $\mathrm{Ca}, \mathrm{Fe}$ and $\mathrm{K}$ counts are high throughout the zone.

\section{Zone SE2: 5400-3600 cal year BP}

In Zone SE2, the subfamily Orthocladiinae and the genera Chironomus and Paratanytarsus disappear almost completely from the assemblages, resulting in higher relative abundances of Micropsectra radialis- planktonic/periphytic diatom ratio (right). Data are plotted on a sediment depth scale $(\mathrm{cm})$ with an age scale (cal year BP) for reference. Zonation (SE1-SE4) follows the chironomid assemblages. (Color figure online)

type $(\sim 80 \%)$. The ratio between the $M$. radialis subtypes remains similar, with $M$. radialis type HEIRI accounting for $66 \%, M$. radialis type $\mathrm{T} 1$ for $28 \%$ and $M$. radialis type $\mathrm{T} 2$ for $5 \%$ of the morphotype sum, respectively. The head capsule concentrations increase abruptly at the onset of Zone SE2, showing extremely high values throughout the zone (on average $91.9 \mathrm{HC} \mathrm{g}^{-1}$ dry). Throughout Zone SE2, only periphytic diatoms occur. Most abundant are Ellerbeckia arenaria Moore ex Ralfs ( $\sim 40 \%)$, Cocconeis cf. pseudothumensis Reichardt ( 40\%) and Karayevia clevei (Grunow) Bukhtivarova ( 20\%). The diatom concentrations are comparably low throughout the zone $\left(0.8 \times 10^{7}\right.$ valves $\left.\mathrm{g}^{-1} \mathrm{dry}\right)$. In the sediments, an erosive contact is visible at the onset of the zone, with a layer of gravel at the base, overlain by dark grey silt and several intercalated sand layers. Similarly, the Ca counts show an abrupt drop and the lowest values of the whole record during Zone SE2. Fe and K counts show a slight drop at the onset of Zone SE2 and remain constant throughout the zone thereafter. 
Zone SE3: 3600-2100 cal year BP

Abundance of Micropsectra radialis-type in Zone SE3 is similar to that in Zone SE2 $(\sim 80 \%)$. Paratanytarsus reappears in low abundances $(\leq 5 \%)$. The ratio between the $M$. radialis subtypes changes, with $M$. radialis type HEIRI accounting for $55 \%, M$. radialis type $\mathrm{T} 1$ for $18 \%$ and $M$. radialis type $\mathrm{T} 2$ for $27 \%$ of the $M$. radialis-type head capsules. Additionally, the ratio between the three subtypes is variable and fluctuates, with $M$. radialis type HEIRI decreasing when the other two subtypes increase. The head capsule concentrations are relatively low throughout Zone SE3 (on average $14.3 \mathrm{HC} \mathrm{g}^{-1}$ dry). Periphytic and planktonic diatoms are present in similar abundances throughout Zone SE3. Ellerbeckia arenaria and Cocconeis cf. pseudothumensis decrease distinctly at the onset of the zone, whereas Kareyevia clevei remains present, with about $14 \%$. The periphytic taxa Plantothidium and Amphora pediculus (Kützing) Grunow displayed increased proportions $(\sim 10 \%)$ in Zone SE3. The planktonic "small Cyclotella s.l. group" occurs in fluctuating abundances (3.0-66.3\%). Diatom concentrations are very high at the beginning of Zone SE3 (max. $56.8 \times 10^{7}$ valves $\mathrm{g}^{-1}$ dry) and thereafter remain at average values $\left(1.1 \times 10^{7}\right.$ valves $g^{-1}$ dry $)$. Dark grey silt with sparse layers of coarse plant detritus characterize the sediment in Zone SE3. At the onset of the zone, $\mathrm{Ca}$ counts start to increase while $\mathrm{Fe}$ and $\mathrm{K}$ counts start to decrease, a trend that all three elements continue to display throughout the zone.

\section{Zone SE4: 2100 cal year BP to present}

Micropsectra radialis-type continues to show abundances of $\sim 80 \%$ in Zone SE4. Paratanytarsus abundances increase slightly, to as much as $10 \%$. Minor changes are visible in the $M$. radialis subtype-ratio $(M$. radialis type HEIRI $60 \%, M$. radialis type T1 $12 \%$ and $\mathrm{M}$. radialis type $\mathrm{T} 227 \%$ ), and the trends in the subtypes differ. $M$. radialis type HEIRI and $M$. radialis type T1 fluctuate in concert, whereas $M$. radialis type T2 runs contrary to the other two. The head capsule concentrations increase to intermediate values (mean $=28 \mathrm{HC} \mathrm{g}^{-1}$ dry). Zone SE4 is characterized by a steady increase in planktonic diatoms, mainly "small Cyclotella s.l. group." Abundances of periphytic diatoms mostly decrease, and only
Plantothidium is present, at about $12 \%$. Diatom concentrations are relatively high and increase steadily throughout the zone (on average $30.4 \times 10^{7}$ valves $\mathrm{g}^{-1}$ dry). Dark grey silt also characterizes Zone SE4, but layers of coarse plant detritus become more abundant toward the top of the core. Ca counts continue to increase, and $\mathrm{Fe}$ and $\mathrm{K}$ counts decrease further throughout Zone SE4.

\section{Discussion}

Sediment core comparison

The central-lake core and the southeastern, near-shore core show similar compositions and development through time in sedimentological, geochemical and paleoecological indicators. Both cores consist mainly of dark grey silts and show an increase in $\mathrm{Ca}$ and decreases in $\mathrm{Fe}$ and $\mathrm{K}$ during the past ca. 5000 years. Micropsectra radialis-type is the most important chironomid taxon in both cores, and is accompanied by lower abundances of Paratanytarsus at each site. The overall composition of the chironomid fauna reflects the freshwater conditions of Taro Co and the great water depth, 68.0 and $29.4 \mathrm{~m}$ at the two locations (Laug et al. 2020b).

Some differences, however, are noted when the paleoecological records of the two cores are compared in detail. Both chironomid concentrations and the number of rare chironomid taxa are higher in the southeastern core. Additionally, diatom assemblages in the central-lake core show higher abundances of planktonic taxa than those of the southeastern core. These differences between the two cores almost certainly reflect the different locations. Even though both cores were collected from relatively deep-water areas of the lake, the southeastern core was taken closer to shallow-water zones (Fig. 1). Therefore, greater input of sediment transported from shallow parts of the lake is expected at the southeastern core site, potentially carrying with it chironomid taxa and periphytic diatoms. The greater water depth at the central-lake core location might explain the relatively low chironomid concentrations, commonly observed in greater water depths (Heggen et al. 2012; Laug et al. 2020b).

Both cores display similar periods of environmental change during the Middle to Late Holocene. We 
identified zonal boundaries at 5100 and $2400 \mathrm{cal}$ year $\mathrm{BP}$ in the central-lake core, which agree well with zonal boundaries observed at 4900 and 2000 cal year BP in the core from the southeastern site. Differences between the ages of zones in the two cores are mostly within the uncertainty estimates of the radiocarbon dating method. Because these two boundaries are identified in both cores, they are likely caused by lakewide, ecosystem-level changes. We therefore will discuss the paleolimnological development of Taro Co using three lake-wide stages: Stage I, before 5250, Stage II, 5250-2250, and Stage III, from ca. 2250 cal year BP to present.

The southeastern core yields additional information, given its 7000-year-long hiatus (12,400-5400 cal year BP) and a 1800-year-long phase of distinctly different environmental conditions (5400-3600 cal year BP), as suggested by high chironomid concentrations, absence of planktonic diatoms, and extremely low Ca counts (Figs. 5, 6). It is likely that these latter two phases, only observed in the southeastern core, represent local conditions.

\section{Paleoenvironmental history of Taro Co}

Comparison between the two cores during Stage I ( $>$ ca. 5250 cal year BP) is not possible because of the hiatus in the southeastern core $(12,400-5400 \mathrm{cal}$ year BP). In the southeastern core, Stage I is represented only by a short sediment interval dated to $>12,400$ cal year BP (Zone SE1). This zone stands out because of its unique sedimentological and microfossil composition. The sediments are carbonate-rich, and it is the only zone in the southeastern core in which Chironomus is present. Because this genus is known from a broad range of ecological conditions (Laug et al. 2020a), and because the chironomid assemblages of this zone differ little from the rest of the core, it is not possible to provide a reliable interpretation of the environmental conditions during this interval.

In the central-lake core, Stage $\mathrm{I}$ is represented between 7300 and 5100 cal year BP (Zone C1). It is the only part of this core in which Pseudosmittia is present. Even though some species of Pseudosmittia occur in shallow zones of lakes, the genus is commonly interpreted as semi-terrestrial (Strenzke 1950; Laug et al. 2020b). Considering the present water depth at the coring site, it is likely that the
Pseudosmittia head capsules were transported to the core location from shallow areas of the lake. Furthermore, during this zone, TOC and head capsule concentrations are low, indicating low chironomid productivity. When local productivity is low, head capsules transported to the site increase in relative abundance, perhaps explaining the relatively high abundances of the semi-terrestrial taxon Pseudosmittia in this part of the record.

The transition to Stage II is characterized by the largest differences in the record, which was noted for all variables, although the timing of the onset of change differed somewhat among sediment parameters. For most indicators, changes occurred in the time interval 5100-4700 cal year BP, a relatively brief period, with differences in onset perhaps related to differences in sensitivity of bioindicators compared to inorganic variables (Schwarz et al. 2017). The largest difference in response time was observed in TOC, $\mathrm{C} / \mathrm{N}$ ratio and pollen, which responded at $6300 \mathrm{cal}$ year $\mathrm{BP},>1000$ years earlier than the other indicators. This difference might be related to a delayed reaction of the lake ecosystem to a change in the watershed. Pollen is an indicator of terrestrial vegetation (Herzschuh 2007), and TOC, in combination with $\mathrm{C} / \mathrm{N}$ ratios, indicate an increase, probably allochthonous, in productivity (Haberzettl et al. 2010).

The transition from Stage II to Stage III is less pronounced, but characterized by changes in the same direction, in particular by a further increase in the abundances of Paratanytarsus and Ca counts in both cores, as well as a further increase in the Artemisial Cyperaceae ratio. We interpret both transitions as responses to a general, Middle to Late Holocene drying trend, accompanied by a lake level decline and slightly increasing lake-water salinity. The increase in carbonate precipitation over time was likely caused by greater ion concentrations, in turn caused by evaporation and consequent lower lakes levels (Haberzettl et al. 2009). The simultaneous increase of $\mathrm{Ca}$ counts and total inorganic carbon (TIC) values in the upper part of the central-lake core and the general decrease in minerogenic input indicators $(\mathrm{Fe}, \mathrm{K})$ provide additional support for this interpretation. This development is reflected by the decline of Micropsectra radialis-type in favor of Paratanytarsus, Chironomus anthracinus-type and Psectrocladius sordidellus-type. The three latter types, in contrast to M. radialis, all indicate lower lake levels and are to a certain extent 
tolerant of higher salinity (Zhang et al. 2007; Laug et al. 2020b). The most abundant chironomid and diatom taxa, even in the most recent samples, consist of freshwater taxa, reflecting the modern status of the lake, at the limit between fresh and brackish water (0.6 $\left.\mathrm{g} \mathrm{L}^{-1} \mathrm{TDS}\right)$. Proxy variables used as indicators of watershed conditions, TOC, $\mathrm{C} / \mathrm{N}$ ratio and pollen, also suggest a drying trend at both transitions. The rise in the ratio of Artemisia to Cyperaceae can be interpreted as a sign of increasing aridity (Herzschuh 2007), potentially resulting in a sparser vegetation cover, leading to increased erosion, and perhaps explaining the concurrent increase in $\mathrm{C} / \mathrm{N}$ ratio (Haberzettl et al. 2010).

The only proxy record that seems to contradict the interpretation of a trend toward drier conditions and lower lake level is the diatom record. Whereas the transition to high percentages of benthic diatoms at the first stage boundary might suggest a lake level decline, abundance of planktonic diatoms increased during Stage III, suggesting a rise in lake level. Although the ratio of planktonic to periphytic diatoms can, because of the relative abundance of pelagic and littoral habitats, indicate lake level fluctuations (Wolin and Stone 2010), lake basin morphology can play a key role in determining the plankton/periphytic diatom ratio (Stone and Fritz 2004; Wang et al. 2012). We suggest that the increase in planktonic diatoms might be connected with a decrease in the area of periphytic diatom habitat. The Taro Co lake level at 4500 cal year BP was at least $30 \mathrm{~m}$ higher than today (Alivernini et al. 2018) and flat areas along the north and northeast shores of the lake were flooded (Fig. 1). During a lake level decline, such areas at first became shallow-ideal habitats for periphytic diatoms, but subsequently became dry, resulting in a reduction of these habitats, because the modern lake is characterized by steep contours, thus explaining the increase in planktonic diatoms (Wigdahl-Perry et al. 2016; Beck et al. 2019).

Previous results from the Taro Co region support the hypothesis of a Middle to Late Holocene drying trend. A lake level reconstruction based on optical dating of paleoshorelines revealed a decline since the Middle Holocene, including the separation of Taro Co from neighboring Zabuye Salt Lake around 3500-3000 cal year BP (Alivernini et al. 2018). The Middle to Late Holocene drying trend was not limited to the Taro Co region, but seems to have been common in monsoon-affected regions of Central Asia. For the largest lake of the neighboring lake system, Tangra Yumco ( $220 \mathrm{~km}$ east of Taro Co), several studies showed a lake level decline after the Early Holocene (Ahlborn et al. 2015; 2017; Ma et al. 2020). Stable isotope and sedimentological records from Selin Co, the largest lake of Tibet ( $\sim 450 \mathrm{~km}$ east of Taro Co), revealed several drought events that occurred during the past 4000 cal year (Gyawali et al. 2019). Similar to our results, a multi-proxy reconstruction from Nam $\mathrm{Co}$, the second largest Tibetan lake $(\sim 600 \mathrm{~km}$ east of Taro Co) showed a general drying trend that started 4800 cal year BP (Doberschütz et al. 2014).

Local conditions at the southeastern core site

We suggest that relocation of an inflowing river was the main driver of the two local events observed in the southeastern lake core. Today, this river takes a turn about $200 \mathrm{~m}$ from shore and then flows for $\sim 1.6 \mathrm{~km}$ parallel to the shore before entering the lake (Fig. 1). Given the low height of the modern beach ridge, only $\sim 2 \mathrm{~m}$ above the river, a more direct route of past river discharge into the lake is plausible.

At 5400 cal year BP, the climate around Taro Co was more humid than today, suggesting greater river discharge (Alivernini et al. 2018; Ma et al. 2020). If the river broke through the beach ridge, currents associated with discharge could have been strong enough to erode sediment at the core location, and may have been responsible for the first local event, the 7000-year-long hiatus between 12,400 and $5400 \mathrm{cal}$ year BP. This interpretation is supported by our lithological results, as sedimentation resumed with a layer of gravel after the hiatus, indicating high current velocities. Internal lake processes that could cause a hiatus in lake sedimentation, such as stage declines that result in subaerial exposure of the coring location (Haberzettl et al. 2009), are not documented in the central core and are therefore unlikely. Other external causes, such as earthquakes, cannot at this time be rejected.

Following the hiatus, all variables in the southeastern core between 5400 and 3600 cal year BP indicate distinct environmental conditions. We interpret this as reflecting a more direct route of the river into the lake. Under such conditions, the core location would have been on the delta, instead of at its modern location on part of the prodelta (Fig. 7). This interpretation would 


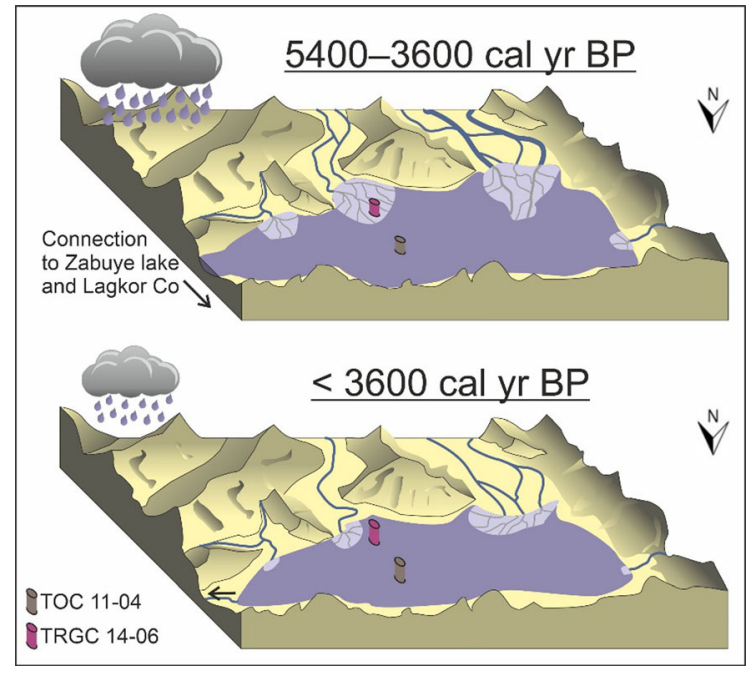

Fig. 7 Potential form of Taro Co and its tributaries under different monsoon activity. Core locations are indicated showing the position of both sediment cores in relation to the river delta of Taro Co's southeastern tributary

explain the coarser grain sizes observed during this time (Fig. 2). It would also explain the low Ca counts (Fig. 5), as the fresh water delivered by the current might have hindered calcium precipitation at the site. Furthermore, high chironomid concentrations observed in this interval (Fig. 5) could be consistent with this interpretation, as head capsules would have been transported from the more densely populated shallower areas to the core location. The end of this interval might have been triggered by the formation of the modern beach ridge, under drier conditions and reduced river discharge, resulting in a different river route and placing the southeastern core location as part of the river prodelta. In addition to the first river relocation, we propose that the river migrated over the course of these 1800 years, explaining the gradient in grain sizes from gravel to sand, as well as changes in chironomid concentrations and diatom species compositions in the first part of Zone SE2.

The diatom results substantiate the interpretation of changing river routes into the lake. Between 5400 and 3600 cal year BP, Ellerbeckia arenaria dominated the diatom assemblages. This species was found in sediments of turbid Central Canadian Rocky Mountain lakes, which are characterized by the high influence of glacial meltwater (Hickman and Reasoner 1994). Furthermore, E. arenaria, considered to be a subaerial species, grows on wet stones and tolerates extreme water depth fluctuations (Schmid and Crawford 2001; Krammer and Lange-Bertalot 2008), such as those found in river deltas. E. arenaria could also have been transported via glacial meltwater into downstream areas (Krammer and Lange-Bertalot 2008), which in turn could have transported the valves to the core location (Hickman and Reasoner 1994). After the second relocation of the southeastern river at 3600 cal year BP, "small Cyclotella s.l. group" prevails, a species group that prefers stable conditions and high light availability (Rioual et al. 2007).

The composition of the chironomid fauna during the interval between 5400 and 3600 cal year BP shows only two of the three Micropsectra radialis subtypes. Presently, the ecological preferences of each of these subtypes are unknown. Furthermore, the subtypes are based on morphological differences and do not necessarily belong to different species, but could alternatively represent different larval instars of the same species. Therefore, the different abundances of the subtypes, in particular the low abundances of M. radialis type $\mathrm{C}$ in Zone SE1 and SE2, could suggest different ecological conditions, but could also be related to differential preservation of subtypes as a result of size differences and degree of chitinization.

\section{Conclusions}

We analyzed two sediment cores from Tibetan lake Taro Co, and found evidence for a general Middle to Late Holocene drying trend, as well as evidence for two lake-wide, ecosystem-level changes, at ca. 5250 and $2250 \mathrm{cal}$ year BP. As a result of drier conditions, the lake level declined and lake water salinity increased slightly throughout the Holocene. The twin-core approach enabled us to distinguish between lake-wide changes and local conditions, detected only in the core located close to the southeastern shore. A sedimentation hiatus spanning 12,400-5400 cal year $\mathrm{BP}$ and a phase of different environmental conditions between 5400 and 3600 cal year BP were identified in that sediment core. We attribute both local events to migration of a river that discharges in the southeast sector of the lake. More direct flow into the lake, resulting from higher flow, is certainly plausible and contrasts with the modern river course, which takes a turn and runs parallel to the shore. This hypothesis would explain the hiatus as well as the phase 
afterwards, in which the core location would have been situated on the delta.

Acknowledgements The German Federal Ministry of Education and Research (BMBF) sponsored our work within the joint project CAHOL (FKZ 03G0864C). Research was supported by CAS Fellowships for Young International Scientists (Grant No. 2013Y2ZB0001) and the NSFC Research Fund for International Young Scientists (Grant No. 41450110075). This work was also part of the Sino-German collaboration within the DFG priority program 1372 "TiP Tibetan Plateau: Formation-Climate-Ecosystem" (Grant No. MA1308/23-2) and was jointly financed by the National Natural Science Foundation of China (Grant No. 41877168). XRFscanning of TOC11-4 was carried out at GEOPOLAR, University of Bremen, Germany.

Open Access This article is licensed under a Creative Commons Attribution 4.0 International License, which permits use, sharing, adaptation, distribution and reproduction in any medium or format, as long as you give appropriate credit to the original author(s) and the source, provide a link to the Creative Commons licence, and indicate if changes were made. The images or other third party material in this article are included in the article's Creative Commons licence, unless indicated otherwise in a credit line to the material. If material is not included in the article's Creative Commons licence and your intended use is not permitted by statutory regulation or exceeds the permitted use, you will need to obtain permission directly from the copyright holder. To view a copy of this licence, visit http://creativecommons.org/licenses/by/4.0/.

Funding Open Access funding enabled and organized by Projekt DEAL.

\section{References}

Ahlborn M, Haberzettl T, Wang J, Fürstenberg S, Mäusbacher R, Mazzocco J, Pierson J, Zhu L, Frenzel P (2015) Holocene lake level history of the Tangra Yumco lake system, southern-central Tibetan Plateau. Holocene 26:176-187

Ahlborn M, Haberzettl T, Wang J, Henkel K, Kasper T, Daut G, Zhu L, Mäusbacher R (2017) Synchronous pattern of moisture availability on the southern Tibetan Plateau since 17.5 cal. ka BP: the Tangra Yumco lake sediment record. Boreas 46:229-241

Alivernini M, Lai Z, Frenzel P, Fürstenberg S, Wang J, Guo Y, Peng P, Haberzettl T, Börner N, Mischke S (2018) Late Quaternary lake level changes of Taro Co and neighbouring lakes, southwestern Tibetan Plateau, based on OSL dating and ostracod analysis. Glob Planet Change 166:1-18

Anslan S, Azizi Rad M, Buckel J, Echeverria Galindo P, Kai J, Kang W, Keys L, Maurischat P, Nieberding F, Reinosch E, Tang H, Tran TV, Wang Y, Schwalb A (2020) Reviews and syntheses: How do abiotic and biotic processes respond to climatic variations in the Nam Co catchment (Tibetan Plateau)? Biogeosciences 17:1261-1279

Battarbee RW, Kneen MJ (1982) The use of electronically counted microspheres in absolute diatom analysis. Limnol Oceanogr 27:184-188

Beck K, Fletcher M, Gadd P, Heijnis H, Saunders KM, Zawadzki A (2019) The long-term impacts of climate and fire on catchment processes and aquatic ecosystem response in Tasmania, Australia. Quaternary Sci Rev 221:105892

Bennett KD (1996) Determination of the number of zones in a biostratigraphical sequence. New Phytol 132:155-170

Beug HJ (2004) Leitfaden der Pollenbestimmung für Mitteleuropa und angrenzende Gebiete. [Book in German] Dr. Friedrich Pfeil, München

Birks HH, Birks HJB (2006) Multi-proxy studies in palaeolimnology. Veg Hist Archaeobot 15:235-251

Blaauw M, Christen JA (2011) Flexible paleoclimate age-depth models using an autoregressive gamma process. Bayesian Anal 6:457-474

Blott SJ, Pye K (2001) GRADISTAT: a grain size distribution and statistics package for the analysis of unconsolidated sediments. Earth Surf Proc Land 26:1237-1248

Börner N, De Baere B, Akita LG, Francois R, Jochum KP, Frenzel P, Zhu L, Schwalb A (2017) Stable isotopes and trace elements in modern ostracod shells: Implications for reconstructing past environments on the Tibetan Plateau, China. J Paleolimnol 58:191-211

Brooks SJ, Langdon PG, Heiri O (2007) The identification and use of Palaearctic Chironomidae larvae in palaeoecology. Quaternary Research Association, London

Digerfeldt G (1986) Studies on past lake-level fluctuations. In: Berglund BE (ed) Handbook of Holocene palaeoecology and palaeohydrology. Wiley, Chichester, pp 127-143

Doberschütz S, Frenzel P, Haberzettl T, Kasper T, Wang J, Zhu L, Daut G, Schwalb A, Mäusbacher R (2014) Monsoonal forcing of Holocene paleoenvironmental change on the central Tibetan Plateau inferred using a sediment record from Lake Nam Co (Xizang, China). J Paleolimnol 51:253-266

Everitt B, Landau S, Leese M, Stahl D (2011) Cluster analysis, 5th edn. John Wiley and Sons, Chichester

Guo Y, Zhu L, Frenzel P, Ma Q, Ju J, Peng P, Wang J, Daut G (2016) Holocene lake level fluctuations and environmental changes at Taro Co, southwestern Tibet, based on ostracodinferred water depth reconstruction. Holocene 26:29-43

Gyawali AR, Wang J, Ma Q, Wang Y, Xu T, Guo Y, Zhu L (2019) Paleo-environmental change since the Late Glacial inferred from lacustrine sediment in Selin Co, central Tibet. Palaeogeogr Palaeocl 516:101-112

Haberzettl T, Anselmetti F, Bowen S, Fey M, Mayr C, Zolitschka B, Ariztegui D, Mauz B, Ohlendorf C, Kastner S, Lücke A, Schäbitz F, Wille M (2009) Late Pleistocene dust deposition in the Patagonian steppe - extending and refining the paleoenvironmental and tephrochronological record from Laguna Potrok Aike back to $55 \mathrm{ka}$. Quaternary Sci Rev 28:2927-2938

Haberzettl T, Daut G, Schulze N, Spiess V, Wang J, Zhu L (2019) ICDP workshop on scientific drilling of Nam Co on the Tibetan Plateau: 1 million years of paleoenvironmental history, geomicrobiology, tectonics and paleomagnetism 
derived from sediments of a high-altitude lake. Sci Drilling 25:63-70

Haberzettl T, Henkel K, Kasper T, Ahlborn M, Su Y, Wang J, Appel E, St-Onge G, Stoner J, Daut G, Zhu L, Mäusbacher $R$ (2015) Independently dated paleomagnetic secular variation records from the Tibetan Plateau. Earth Planet Sc Lett 416:98-108

Haberzettl T, St-Onge G, Lajeunesse P (2010) Multi-proxy records of environmental changes in Hudson Bay and Strait since the final outburst flood of Lake Agassiz-Ojibway. Mar Geol 271:93-105

Heggen MP, Birks HH, Heiri O, Grytnes JA, Birks HJB (2012) Are fossil assemblages in a single sediment core from a small lake representative of total deposition of mite, chironomid, and plant macrofossil remains? J Paleolimnol 48:669-691

Herzschuh U (2007) Reliability of pollen ratios for environmental reconstructions on the Tibetan Plateau. J Biogeogr 34:1265-1273

Hickman M, Reasoner MA (1994) Diatom responses to late Quaternary vegetation and climate change, and to deposition of two tephras in an alpine and a sub-alpine lake in Yoho National Park, British Columbia. J Paleolimnol 11:173-188

Houk V, Klee R, Hiroyuki T (2014) Atlas of freshwater centric diatoms with a brief key and descriptions: Part IV: Stephanodiscaceae B. Fottea 14: Supplement

Houk V, Klee R, Tanaka H (2010) Atlas of freshwater centric diatoms with a brief key and descriptions, Part III. Stephanodiscaceae A. Cyclotella, Tertiarius, Discostella. Fottea 10: Supplement

Immerzeel WW, van Beek LPH, Bierkens MFP (2010) Climate change will affect the Asian water towers. Science 328:1382-1385

Jiang L, Nielsen K, Andersen OB, Bauer-Gottwein P (2017) Monitoring recent lake level variations on the Tibetan Plateau using CryoSat-2 SARIn mode data. J Hydrol 544:109-124

Kasper T, Haberzettl T, Doberschütz S, Daut G, Wang J, Zhu L, Nowaczyk N, Mäusbacher R (2012) Indian Ocean Summer Monsoon (IOSM)-dynamics within the past $4 \mathrm{ka}$ recorded in the sediments of Lake Nam Co, central Tibetan Plateau (China). Quaternary Sci Rev 39:73-85

Kou Q, Lin X, Wang J, Yu S, Kai J, Laug A, Zhu L (2020) Spatial distribution of n-alkanes in surface sediments of Selin Co Lake, central Tibetan Plateau, China. J Paleolimnol

Krammer K, Lange-Bertalot H (2008) Süßwasserflora von Mitteleuropa, 2/2: Bacillariaceae, Epithemiaceae. Spektrum Akademischer Verlag, Heidelberg, Surirellaceae

Lange-Bertalot H, Hofmann G, Werum M, Cantonati M (2017) Freshwater benthic diatoms of central Europe: over 800 common species used in ecological assessment. Koeltz Botanical Books, Oberreifenberg

Laug A, Hamerlík L, Anslan S, Engels S, Turner F, Wang J, Schwalb A (2019) Acricotopus indet. morphotype incurvatus. Description and genetics of a new Orthocladiinae (Diptera: Chironomidae) larval morphotype from the Tibetan Plateau. Zootaxa 4656:535-544

Laug A, Schwarz A, Lauterbach S, Engels S, Schwalb A (2020a) Ecosystem shifts at two mid-Holocene tipping points in the alpine Lake Son Kol (Kyrgyzstan, Central Asia). Holocene 30:1410-1419

Laug A, Turner F, Engels S, Wang J, Haberzettl T, Ju J, Yu S, Kou Q, Börner N, Schwalb A (2020b) Is there a common subfossil chironomid distribution threshold at $16 \mathrm{~m}$ water depth? Evidence from the Tibetan Plateau. J Limnol

Ma Q, Zhu L, Lü X, Guo Y, Ju J, Wang J, Wang Y, Tang L (2014) Pollen-inferred Holocene vegetation and climate histories in Taro Co, southwestern Tibetan Plateau. Chin Sci Bull 59:4101-4114

Ma Q, Zhu L, Wang J, Ju J, Wang Y, Lü X, Kasper T, Haberzettl $\mathrm{T}$ (2020) Late Holocene vegetation responses to climate change and human impact on the central Tibetan Plateau. Sci Total Environ 708:135370

Malhi Y, Franklin J, Seddon N, Solan M, Turner MG, Field CB, Knowlton N (2020) Climate change and ecosystems: threats, opportunities and solutions. Philos Trans R Soc Lond Ser B Biol Sci 375:20190104

Mohan J, Stone JR, Nicholson K, Neumann K, Dowling C, Sharma S (2018) Lindavia biswashanti, a new diatom species (Bacillariophyta) from Gokyo Cho, Himalayan Range. Nepal Phytotaxa 364:101-107

Nakagawa T (2007) Double-L channel: an amazingly non-destructive method of continuous sub-sampling from sediment cores. Quaternary International. 17th INQUA Congress, Cairns

Oksanen J, Blanchet R, Friendly M, Kindt R, Legendre P, McGlinn D, Minchin P, O’Hara R, Simpson G, Solymos P, Stevens M, Szoecs E, Wagner H (2016) Vegan: Community Ecology Package. R Package Vers. 2.4e1

Quinlan R, Smol JP (2001) Setting minimum head capsule abundance and taxa deletion criteria in chironomid-based inference models. J Paleolimnol 26:327-342

Reimer PJ, Austin WEN, Bard E, Bayliss A, Blackwell PG, Bronk Ramsey C, Butzin M, Cheng H, Edwards RL, Friedrich M, Grootes PM, Guilderson TP, Hajdas I, Heaton TJ, Hogg AG, Hughen KA, Kromer B, Manning SW, Muscheler R, Palmer JG, Pearson C, van der Plicht J, Reimer RW, Richards DA, Scott EM, Southon JR, Turney CSM, Wacker L, Adolphi F, Büntgen U, Capano M, Fahrni SM, Fogtmann-Schulz A, Friedrich R, Köhler P, Kudsk S, Miyake F, Olsen J, Reinig F, Sakamoto M, Sookdeo A, Talamo S (2020) The IntCal20 Northern Hemisphere radiocarbon age calibration curve $(0-55 \mathrm{kcal} \mathrm{BP})$. Radiocarbon 62:725-757

Rioual P, Andrieu-Ponel V, de Beaulieu JL, Reille M, Svobodova H, Battarbee RW (2007) Diatom responses to limnological and climatic changes at Ribains maar (French massif Central) during the Eemian and early Würm. Quaternary Sci Rev 26:1557-1609

Schmid AMM, Crawford RM (2001) Ellerbeckia arenaria (Bacillariophyceae): formation of auxospores and initial cells. Eur J Phycol 36:307-320

Schwarz A, Turner F, Lauterbach S, Plessen B, Krahn KJ, Glodniok S, Mischke S, Stebich M, Witt R, Mingram J, Schwalb A (2017) Mid- to late Holocene climate-driven regime shifts inferred from diatom, ostracod and stable isotope records from Lake Son Kol (Central Tian Shan, Kyrgyzstan). Quaternary Sci Rev 177:340-356

Stone JR, Fritz SC (2004) Three dimensional modeling of lacustrine diatom habitat areas: improving 
paleolimnological interpretation of planktic: benthic ratios. Limnol Oceanogr 49:1540-1548

Strenzke K (1950) Systematik, Morphologie und Ökologie der terrestrischen Chironomiden. Archiv für Hydrobiologie 18: Supplement

Turner F, Zhu L, Lü X, Peng P, Ma Q, Wang J, Hou J, Lin Q, Yang R, Frenzel P (2016) Pediastrum sensu lato (Chlorophyceae) assemblages from surface sediments of lakes and ponds on the Tibetan Plateau. Hydrobiologia 771:101-118

Wang Q, Yang X, Hamilton PB, Zhang E (2012) Linking spatial distributions of sediment diatom assemblages with hydrological depth profiles in a plateau deep-water lake system of subtropical China. Fottea 12:59-73

Wigdahl-Perry CR, Saros JE, Schmitz J, Calcote R, Rusak J, Anderson D, Hotchkiss S (2016) Response of temperate lakes to drought: a paleolimnological perspective on the landscape position concept using diatom-based reconstructions. J Paleolimnol 55:339-356

Wolin JA, Stone JR (2010) Diatoms as indicators of water-level change in fresh-water lakes. In: Smol JP, Stoermer EF (eds) The diatoms: applications for the environmental and earth sciences, 2nd edn. Cambridge University Press, Cambridge, pp 174-185

Wu Y, Zhang X, Zheng H, Li J, Wang Z (2017) Investigating changes in lake systems in the south-central Tibetan Plateau with multi-source remote sensing. J Geogr Sci 27:337-347
Yao T, Pu J, Lu A, Wang Y, Yu W (2007) Recent Glacial Retreat and Its Impact on Hydrological Processes on the Tibetan Plateau, China, and Surrounding Regions. Arct Antarct Alp Res 39:642-650

Yu S, Wang J, Li Y, Peng P, Kai J, Kou Q, Laug A (2019) Spatial distribution of diatom assemblages in the surface sediments of Selin Co, central Tibetan Plateau, China, and the controlling factors. J Great Lakes Res 45:1069-1079

Zhang E, Jones R, Bedford A, Langdon PG, Tang H (2007) A chironomid-based salinity inference model from lakes on the Tibetan Plateau. J Paleolimnol 38:477-491

Zhang T, Li T, Cheng H, Edwards RL, Shen C, Spötl C, Li H, Han L, Li J, Huang C, Zhao X (2017) Stalagmite-inferred centennial variability of the Asian summer monsoon in southwest China between 58 and 79 ka BP. Quaternary Sci Rev 16:1-12

Zhao L, Ding R, Moore JC (2014) Glacier volume and area change by 2050 in high mountain Asia. Global Planet Change 122:197-207

Zheng M, Xiang J, Wei X, Zheng Y (1989) Saline lakes on the Qinghai-Xizang (Tibet) Plateau. Beijing Scientific and Technical Publishing House, Beijing

Publisher's Note Springer Nature remains neutral with regard to jurisdictional claims in published maps and institutional affiliations. 